\title{
Designing Accounting Information System for Trading SMEs: Empirical and Islamic Integration Approach
}

\author{
Yuniarti Hidayah Suyoso Putra ${ }^{1 *}$, Sri Yati2 \\ 1 Department of Accounting, Faculty of Economics, UIN Maulana Malik Ibrahim Malang, Indonesia \\ 2 Department of Management, STIE Malangkuseswara Malang, Indonesia. \\ * Corresponding author.Email: yuniarti_hidayah@yahoo.com \\ Manuscript submitted August 04, 2014; accepted October 13, 2017.
}

\begin{abstract}
This research aims to describe the implementation of the accounting information system in the Small and Medium Enterprises (SMES) which engaged in trading activities and provide recommendations to develop the accounting information system to support SMES regarding best practices day to day operations and business side in Islam. The research uses mixed methods that attempt to bring together quantitative data and qualitative data to obtain a comprehensive analysis of the research problems. Trading SMEs have become the focused of research. Data collection are through observation, interviews, and documentation techniques. The analysis was performed using the accounting information system design regarding best practices and the business side of Islam. The results showed the sales process in trading SME used cash basis. The results analysis of weaknesses and strength of the accounting information system performance indicates that trading SMES require the improvement concerning organizational structure, job descriptions, and internal controls related to inventory and fixed asset management. These results are used as a foundation to propose the new design of accounting information system without repeating the same mistakes in achieving corporate goals.
\end{abstract}

Keywords: Accounting Information System, Design, Trading SMEs, Islamic Integration.

\section{Introduction}

SMEs hold a strategic role in the economy of a country, but high competition level in the business provokes the SMEs in a less favorable position. The findings specified that the majority of SMEs conduct the business in traditional ways. Therefore, there are a lot of opportunities that are not well exploited by SMEs. The SMEs need something to improve productivity, which it can support their competitiveness through improving the accuracy, validation of data, and the speed of decision making. Thus, accounting information system could be a solution for SMEs in their efforts to provide accurate and valid data [1].

Previous research showed a weak implementation of the accounting information system on SMEs [2]. The reasons include lack of preparation on the organizational side of SMEs, which is caused by low levels formality to divide tasks and responsibilities, high turnover positions or roles [3]. Furthermore, 
many SMEs do not have sufficient resources or not willing to use most of their resources due to the period of implementation and high costs in implementation [4]. As a result, the companies incurred the difficulty in adopting the accounting information system. Reference [5] has researched 72 SMEs in Chinhoyi, Zimbabwe, found several problems related to the implementation of AIS. For example, lack of government support, financial constraints, and the complexity of the accounting information system affected the adoption by SMEs.

Reference [6] revealed evidence that there is still a few types of research on accounting information system in micro-enterprises in developing countries. Hence, the research in this field is still wide open. Reference [7] showed that the accounting information system had been neglected in research related to small businesses, although the accounting information system is essential for business success. While large-scale enterprises have been using computers for some time, SMEs are slow to adopt this innovative technology that also can have an impact on economic development. The need for the availability of accurate and valid data, as well as how to improve competitiveness are emergent. For example, how to increase efficiency process to achieve customer satisfaction, then, the implementation of accounting information systems can be a solution for SMEs. Based on the underlying background and the uniqueness of this study, the issues raised are how the implementation of the accounting information system in SMEs during this time and what are the proposed recommendations in developing accounting information system to support SMEs operation regarding best practices and the business side of Islam?

Therefore, this study aims to describe the implementation of accounting information system in trading SMEs and provide recommendations to develop accounting information system to support SME daily operational based on best practices and the business side of Islam. The findings of research can provide an adequate recommendation to the design of the accounting information system from the practical side and by Islamic law. The results will help the SMEs, first, in collecting and storing data related to the activities undertaken by the organization. Second, in transforming data into the useful information for decision-making, thereby enabling the management to plan, implement, and control activities. Third, providing sufficient controls to save the assets of organization

\section{Literature Review}

\subsection{The Importance of Accounting Information System in Business}

The importance of the widespread use of information systems in many enterprises is to automate existing operations and to improve business activities efficiency. The growing firms and transactions implied that there would be more accounting data needed to recorded and updated. Prior traditional accounting method of manually inputting and recording daily transactions has become inefficient. Errors such as wrong data entry, inefficient tasks performance and massive utilization of paper products have created many problems for business activities and organization's performance. These inadequacies have led to the emergence of accounting information system. Accounting information system helps to gather, analyze and produce reports more efficiently. The evidence from Malaysian SMEs indicated that firms adopting or using accounting information system had significantly increased their companies' profitability and performance. SMEs do use accounting system would be able to collect more information to assist decision-making and to create competitive advantage due to improvement in efficiency and firms' profitability [8].

Reference [1] specifies the majority of SMEs does business in traditional ways, so the opportunities that did not be developed by SMEs. Therefore, to improve the competitiveness, accounting 
information system could be a solution for SMEs in their efforts to provide accurate and valid data. The SMEs need something to improve productivity, which it can enhance their competitiveness trough improve the accuracy, validation of data, and the speed of decision-making. Thus, SMEs accounting information systems were developed based on the characteristics of SMEs.

The competitive advantage of business Information technology that a few years ago was within reach of only large companies can now be employed by SMEs, thereby increasing their competitive advantage [5]. Competitive advantage is gained through efficient processing of customer orders thereby improving customer satisfaction. Accounting information system provides an opportunity for business to improve their efficiency and effectiveness in decision-making. The system assists the firms to gain competitive advantage, cover the fullest range of organizational activities and processes, achieve substantial cost savings and improve access to tried and tested solutions as they also provide an opportunity to update procedures and align them with perceived examples of best practice [9]. Lack of accounting information system adoption will contribute to small enterprise failure, poor decision making by SMEs as information from their records is mainly in the form of incomplete records [5], and creating the barrier that prevented external accountants from providing accurate and reliable management accounts reports.

\subsection{SME Development}

SMEs have a major role in the national economy. In Indonesia, the existence of SMEs has been able to be a source of community living and absorbing more labor, despite having relatively smaller value-added contribution than the Large-scale enterprises. Data from the Indonesian Central Bureau of Statistics highlighted the contribution of employment by SMEs is higher than the labor absorption provided by Large Business. In 2011, the large company was only able to employ 2,891,224 people and amounted 3,150,645 people in 2012. A Large company is only able to accommodate $2.76 \%$ and $2.84 \%$ of the total employment in 2011 and in 2012 respectively [10].

A line with the recent survey of ACCA [11] in 14 Asia Pacific countries, the number of Indonesian SMEs is the second largest after Japan, counted 700,000 SMEs, contribute $99.9 \%$ of total business, absorb more employment and contribute to $57.1 \%$ to GDP. Comparing to the neighborhood countries in Asia such as Singapore, Philippines, Malaysia, Thailand and Vietnam, Indonesian SMEs has the highest numbers and contribution to national GDP.

\section{Methods}

All trading SMEs are located in Malang Region, East Java, and meet the criteria based on the Law of the Republic of Indonesia No. 20 of 2008 on Micro, Small and Medium Enterprises (MSMEs) [12]. The SME standards under the law are as follows.

Table 1. SME Standards based on the Law of the Republic of Indonesia No. 20 of 2008 on MSMEs

\begin{tabular}{ll}
\hline Classification & Daily Sales Turnover \\
\hline Micro & $<$ Rp. 900 thousand \\
Small & Rp. 900 thousand $-<$ Rp. 7,5 thousand \\
Medium & Rp. 7,5 thousands $-<$ Rp. 150 thousand \\
\hline \hline
\end{tabular}

Trading SMEs as research subjects are selected using random sampling. All selected trading SMEs must have the motivation and commitment to improve and develop the accounting information system in their companies. Final trading SMEs as the focus of research is 12 SMEs, while the object of 
the study concentrated on the accounting information system applied in the trading SME.

The study was conducted using mixed methods that bring together the quantitative and qualitative data to obtain a comprehensive analysis of the research problem [13]. Quantitative and qualitative data are collected through observation, interviews, questionnaires, and documentation to illustrate the implementation of the accounting information system applied in trading SMEs. The data gathered in this research is in the form of primary data and secondary data. Primary data is obtained directly by researchers from respondents or informants to be reprocessed to find the answers. Secondary data is the data obtained from the second party or data that does not need to be reprocessed by the researchers. The secondary data includes the organizational structure, job descriptions, chart of accounts, journals, procedures, cost accounting, documentation, and accounting policies of the organization.

Data analysis performed in four steps. First, creating research note during the fieldwork. Second, grouping a similar data from interview results associated with the implementation of accounting information systems in trading SMEs. Third, performing an analysis of the obtained data and used it as the basis to evaluate the weaknesses and the strength of the system implemented by SMEs. Fourth, providing the recommendations to improve accounting information system on the practical side, healthy business practices and the sharia implementation based on the study of Qur'an and Hadith.

\section{Result and Discussion}

The research results are obtained based on the steps of preparing accounting information system are consisted of four focuses that are (1) Analyzing the existing accounting information system, (2) Planning the accounting information system, (3) Applying accounting information systems, and (4) Supervising the new system.

\subsection{Analyzing the Existing Accounting Information System}

This step is intended to determine the weakness and the strength of the existing system. This study performed a preliminary observation which aims to establish the scope of work and plan the period to prepare the system [14]. Analyzing steps of accounting information system carried out in the trading SME involves two things, i.e., an understanding of the business processes and evaluating the weaknesses and the strength of exiting the system.

12 trading SMEs that have become the focus of this research, all are had a superior product variation as their trademark. Following the characteristics of a trading company that does not change the form of goods, the types of product sales are range from retail stores, selling cassava or yams, selling building materials, sacks, glassware or potteries, and veils. The result associated with the legal form of the business showed that 11 of 12 trading SMEs are in the form proprietorship companies and one SME in the form of CV. Meanwhile, the results related to the amount of daily sales turnover of 12 trading SMEs can be classified as follows.

Table 2. Data Classification Based on Daily Sales Turnover

\begin{tabular}{ccc}
\hline Classification & Daily Sales Turnover & $\begin{array}{c}\text { Number of Trading } \\
\text { SMEs }\end{array}$ \\
\hline Micro & < Rp. 900 thousand & 2 \\
Small & Rp. 900 thousand - < Rp. 7,5 thousand & 9 \\
Medium & Rp. 7,5 thousands - < Rp. 150 thousand & 1 \\
& Total & $\mathbf{1 2}$ \\
\hline
\end{tabular}




\section{Source: Data analysis}

Table 2 indicates two trading SMEs categorized as micro-enterprises, nine SMEs classified as small enterprises and one SMEs as businesses in the medium level. The observation results also showed only one of 12 trading SMEs that has become the member of the cooperative. The participation as a member of cooperative has become one of the interviews elements with the assumption that as a member of a cooperative, SMEs have access to the funding sources as well as obtain supervision from local cooperatives or Ministry of Cooperatives, Small and Medium Enterprises. The result also illustrates that in operation, the majority of trading SMEs use their private capital rather than debt considering the type of legal entity as proprietorship companies.

Table 3 shows the results of research related to the general description of the accounting information system and internal control activities are carried out in 12 trading SMEs. Before design the appropriate accounting information system, it is necessary to understand the business processes of trading SMEs. Reference [9] underlined that the understanding of AlS within the organization aimed to comprehend whether the existing system has achieved considerable cost savings, the ability to increase the solution creation as it allows a continuous improvement, correct or update the procedures and able to make adjustments following best practices.

Table 3 also indicates that $83 \%$ of trading SMEs surveyed has no clear organizational structure. As a result, the companies do not have clear segregation of duties and authority. In general, most of trading SMEs have simple finance, and accounting manuals, at least they have the cash and bank revenues or disbursements. Bookkeeping functions did not separate completely from the cash receipts and disbursements' function, purchasing function, and inventory functions because of limited available resources regarding quantity or inadequate competence human resources. All personnel who takes regular leave rights handed over routine tasks and all the responsibilities to other staff. Although the job of bookkeeping is rotated by other employee and due to the time limit, the rotation has not sufficiently revealed the irregularities. One reason is the company owned and managed by family members thereby weakened the monitoring activities carried out by the owner.

Furthermore, the use of computer tools for bookkeeping is still a minimum. Most of the accounting activities performed manually. If the SME is using the computer, the data security level is still low because of shared access to the computer. The company also has not had a security guard to check every person or vehicle in and out of the company's locations. Simple financial reports are made periodically to the management. $63 \%$ of trading SMEs surveyed have not been using adequate budgeting as a tool to control expenses and costs. Meanwhile, approximately $58 \%$ of trading SMEs surveyed have a trade partner or supplier who maintained privileged. The average transaction carried out in trading SMEs is based on the cash basis so that the company mostly does not have the term of credit agreement. 
Table 3. The Description of Trading SMEs Accounting Information System

\begin{tabular}{|c|c|c|c|}
\hline \multirow[t]{2}{*}{ A. } & \multirow[t]{2}{*}{ Indicator } & \multicolumn{2}{|c|}{ Disclose } \\
\hline & & Yes (\%) & No $(\%)$ \\
\hline 1 & The existence of organizational structure & 17 & 83 \\
\hline 2 & The company has the personnel job descriptions & 42 & 58 \\
\hline 3 & The company has the financial and accounting manual & 50 & 50 \\
\hline 4 & $\begin{array}{l}\text { Bookkeeping functions are sufficiently separated from cash } \\
\text { receipts and disbursements, purchasing and inventory functions }\end{array}$ & 50 & 50 \\
\hline 5 & $\begin{array}{l}\text { All personnel regularly take his leave right and left his regular } \\
\text { duty to other personnel }\end{array}$ & 58 & 42 \\
\hline 6 & $\begin{array}{l}\text { Other staff rotated bookkeeping tasks, and there is enough turn } \\
\text { time limit to reveal irregularities }\end{array}$ & 8 & 92 \\
\hline 7 & $\begin{array}{l}\text { Companies already processing bookkeeping with computer, } \\
\text { location, and access to the equipment are accessible only by } \\
\text { authorized personnel, and computer input source based on } \\
\text { transaction document }\end{array}$ & 33 & 67 \\
\hline 8 & $\begin{array}{l}\text { Financial statements periodically provided to the } \\
\text { management }\end{array}$ & 33 & 67 \\
\hline 9 & The use of budgeting system to control costs and expenses & 67 & 33 \\
\hline 10 & The existing partners or suppliers particularly retained & 42 & 58 \\
\hline 11 & $\begin{array}{l}\text { Companies have security guards to check every person or } \\
\text { vehicle in and out of the company's locations }\end{array}$ & - & 100 \\
\hline 12 & The company has branch offices & 25 & 75 \\
\hline 13 & The supervision of the branch has done effectively & 33 & 67 \\
\hline 14 & $\begin{array}{l}\text { The credit process should have approval from related } \\
\text { authorities }\end{array}$ & 17 & 83 \\
\hline 15 & The company has the terms of credit agreements & 25 & 75 \\
\hline 16 & $\begin{array}{l}\text { The company has written internal policies, all minute meeting } \\
\text { for decisions, the managers or directors meeting are well } \\
\text { documented and signed neatly }\end{array}$ & 17 & 83 \\
\hline
\end{tabular}

Table 4 describes cash or bank system revenue and disbursements method implemented in the trading SMEs. The administration of cash or bank revenue and disbursements is orderly arranged because of the finance officer stores the chequebook and bank deposit books in an organized manner. Each cash or bank receipts recorded immediately. Bank reconciliations did not always implement under one or both of these two conditions, i.e., first, the accounting records of the companies are similar to the bank, or second, the employee who is responsible for doing the bank reconciliation does not reconcile due to the limitations of their competence. 
Table 4. Cash / Bank Revenue and Disbursement of Trading SMEs

\begin{tabular}{|c|c|c|c|}
\hline \multirow{2}{*}{ B. } & \multirow{2}{*}{ Indicator } & \multicolumn{2}{|c|}{ Disclose } \\
\hline & & Yes (\%) & No (\%) \\
\hline 1 & $\begin{array}{l}\text { Personnel who is responsible for processing and recording the } \\
\text { receipt of cash or bank does not have the authority to process } \\
\text { account receivables and petty cash }\end{array}$ & 17 & 83 \\
\hline 2 & $\begin{array}{l}\text { Cheque register and bank transfer receipt stored in an orderly } \\
\text { manner }\end{array}$ & 83 & 17 \\
\hline 3 & $\begin{array}{l}\text { Independent personnel periodically prepare Bank } \\
\text { reconciliations }\end{array}$ & 8 & 92 \\
\hline 4 & Any cash or bank transaction recorded immediately & 83 & 17 \\
\hline 5 & $\begin{array}{l}\text { Deposit to the bank performed by personnel who are not } \\
\text { related to the task of processing and recording bank receipt }\end{array}$ & 17 & 83 \\
\hline 6 & $\begin{array}{l}\text { Every revenue immediately deposited to the bank, and all } \\
\text { transaction properly recorded in an orderly manner }\end{array}$ & 83 & 17 \\
\hline 7 & $\begin{array}{l}\text { Cash revenue and disbursement is reported periodically to } \\
\text { management }\end{array}$ & 17 & 83 \\
\hline 8 & Budgeting system controls all expenses & 75 & 25 \\
\hline
\end{tabular}

Source: Data analysis

According to the hadith, we are encouraged to have an honest nature. One of the most important moral nature of man is honesty because honesty is the fundamental happiness of society. Honesty involves many aspects, especially related to all matters of life and the welfare of the community. As well as honesty in the case of cash management, cash has a very vulnerable nature as it can be easily transferable without any substantial evidence. Therefore, cash receive and disbursement should be managed as best as possible, efficiently and accountable by providing the evidence without any engineered irregularities. As it can see from the Hadith of Bukhari which says: "Be you all to be honest, because honesty leads to the goodness, and goodness brings to heaven. God will write a person who is always be honest and searching for honesty as an honest man (Siddeeq). And avoid lying, because lying leads to evil, and evil brought to hell. People, who are always lying and looking for lies, will be written by God as a liar (kadzdzab)" [15].

The Qur'an Surat Al-Hujurat verse 6 also highlights the importance of supervision and inspection functions (control and audit) in all activities to avoid disaster for others: "O you who believe! If an unrighteous person comes to you with information, you should verify it or else you might inflict harm on a people in ignorance and then end up regretting what you have done" [16].

If someone holds the position, he or she should be able to maintain and responsible with 'Amanah' or trust, not cheating as well as honesty and knowledgeable because it will bring a lot of trust from the others, as the story of Prophet Yusuf described in the Qur'an Surah Yusuf verse 55 as follows. "[Joseph] said, "Appoint me over the storehouses of the land. Indeed, I will be a knowing guardian" [17].

Regarding receivables transactions, as described in a general overview, the trading SMES conducted the majority transactions in cash-based. Companies do not have account receivables card for each customer since credit in sales are rarely implemented, and as a result, the record of accounts receivable per customer is not examined periodically by late payment.

In Islamic law, debt or loan has known as Al-Qardh. Al-Qardh meaning in etymology (language) is Al-Qath '(disconnected). An asset handed over to the person who owes called Al-Qardh because 
he was cut off by people who are owed money. While according to the syar'i terminology, Al-Qardh means handed asset (money) as a form of affection to anyone who would use it and in return, he would pay back at a time following its equivalent. Initially, the law of debts and receivables are allowed in Islamic law. Giving a loan to someone else who needs it is preferable and recommended because there is a great reward in it. As it revealed in Al-Qur' a Surah Al-Baqarah verse 245: "Who is it that would loan Allah a goodly loan so He may multiply it for him many times? And it is Allah who withholds and grants abundance, and to Him, you will be returned" [18].

Furthermore, the feature of inventory in trading SMEs is the inventory that used as a selling product without changing its shape. Inventories are the assets of the company which occupies an important position in a company, whether it is the trading company or manufacturing company. For a company engaged in the construction field, almost $50 \%$ of the company funding will embedded in the inventory that is to buy building materials [19]. The company has inventory to ensure a smooth business. For a trading company, the availability of merchandising inventory allows the company to meet the demand of the buyers.

The results showed that $83 \%$ of trading SMEs have already managed their inventory in a neat and orderly manner and prevent it from theft, damage, fire or other risks. The company also conducts a simple recording of inventory, for example in the form of an inventory card or notebook to record inventory turnover. Although simple, the inventory transactions well documented. All distributed merchandising to the customers must conform to the distribution letter and must be authorized by the company official. Similarly, damaged goods are separated and recorded separately. However, the real calculation has not carried out routinely. Furthermore, due to limited human resources availability, the result indicated that $75 \%$ of trading SMEs do not have the inventory's supervisor to oversee the company warehouse.

It is necessary to implement the high internal control related to fixed assets to support the accounting information system that aims to facilitate and the accuracy of decision-making processes. The results showed that the addition or subtraction of fixed assets on trading SMEs had not duly authorized during the recording, although there are several trading SMEs already performed adequate maintenance, security, and insurance for assets. Given the urgency of fixed assets of the business flow, $83 \%$ of trading SMEs did not have the list of fixed assets yet as one of the control tools. The depreciation has not implemented, and there were no reviews regarding the existence of damaged fixed assets or idle capacity of fixed assets.

\subsection{Planning the Accounting Information System}

This phase described whether there would be a design of a new system or changing the old system to eliminate and to reduce the weaknesses. There are two different methods to plan the system, using the top-down approach and bottom-up approaches. Both of these approaches selected considering the condition of the company. The sequence of work for a top-down approach is the identification information, account classification and grouping of code included in the general ledger and sub-ledger, journal planning, planning transaction evidence and procedure planning. While the order for a bottom-up approach is starting from planning the transaction's evidence including procedures, planning of journal, planning of account classification code and ends with the resulting information, including forms of the report. The preparation of the accounting system to an organization should consider principles such as speed, security, and the principles of the economy [14]. The design of AIS for trading SME trade based on the understanding of the business processes, the weaknesses, and the strength analyses discussed as follows. 
The existence of a clear organizational structure within an organization represents to whom the performance responsibility aimed to determine whether there is a line of authority or organization staff. Certainty associated with the work condition can determine by translating the organization chart. If the chart or organizational structure is not available, then it should be made in advance. The organizational structure can be used to define the lines of authority and the job responsibility. Many organizations do not know the importance of organizational structures in developing employees to function properly [14].

The job description is a written statement that contains a description of what needs to be done by the personnel, how a job and why the job is done. The description contains about the relationship between a particular position with other positions inside and outside the organization and scope of work in which the personnel is expected to contribute to achieving the goals set by division or business unit as a whole. Thus, job descriptions will make the job can run better and more efficiently.

The chart of accounts is a list of codes for all the estimates transactions included in the company ledger. The chart shows the structure of a company's financial data, which is useful for generating detailed information for the presentation of financial statements [14]. The classification of ledger account based on the group of accounts. Each group has a specific code. The code will divide the data into particular groups and tailored to the order of presentation of information in the Balance Sheet and Profit and Loss calculation. Each group will be coded with numbers so that each digit position has the meaning.

The surveys on transactions have been carried out to determine journals and ledgers used in trading SMEs. Transactions between trading SMEs can be different according to the characteristics of the business process of each company. Phase preparation of journals and ledgers used is a core phase of the entire arranged accounting system. The design journals and ledgers should consider the materiality of decision-making level and the importance of transparency, accountability, and reliability of the produced financial statements.

Trading SMEs can use the Financial Accounting Standards Entities without Public Accountability (SAK ETAP) issued by IAI [20]. This SAK is designed to assist SMEs in preparing financial statements. The purpose financial statements are to provide information about the financial position, financial performance, and cash flows of an entity that is useful to a large number of users in making economic decisions by anyone who is not in a position to ask for financial reports to meet the specific information needs. Financial statements also show what has been done by the management (stewardship) to achieve the objectives or the accountability of management for the resources entrusted to them [20].

Full financial statements by SAK ETAP include the balance sheet, income statement, statement of changes in equity, cash flow statement and notes to the financial statements which contains a summary of significant accounting policies and other explanatory information. Minimal information in the balance sheet includes cash and cash equivalents, accounts receivable and other receivables, inventories, investment property, fixed assets, intangible assets, accounts payable and other debts, assets and tax liabilities, estimated liabilities, equity. Minimal income statement includes the following items: income, financial expenses, profits or losses sharing from investments using equity method, tax expenses, net income or loss [20].

The accounting policies applied in trading SMEs as the focus of research is at least complying the standards set out in the SAK ETAP [20]. The following are the examples of accounting policies can be performed in trading SMEs.

1. Petty Cash 
a. Petty cash fund is cash available to pay the expenses which are relatively small and uneconomical if paid by check.

b. The total amount of petty cash stipulated for certain amount every week or month adjusted for the company's business activities

c. The recording of petty cash used fixed funds system (imprest system). In this system, the number of petty cash accounts always fixed as approved by the board of directors.

d. The petty cash cashier must provide the evidence of expenditure every time he or she makes a payment. At the time of refill, petty cash cashier will hand over the evidence of expenditures and received a check/money for expenses already paid.

e. Petty cash refill will done if the total spending of petty cash has reached $70 \%$ of the maximum amount of petty cash.

\section{Account Receivables}

a. Account receivables presented in the financial statements recognized at the realizable cash value

b. Bad debt Expense. It is necessary to form the allowance for doubtful debts to anticipate losses for doubtful account receivable. The determination of the allowance for doubtful debts can be based on a percentage of credit sales or by other general provisions.

\section{Inventory}

a. Equipment inventories recorded at cost, i.e., the purchase price plus the cost of buying those inventories

b. Equipment inventory system recorded using the perpetual method. In this approach, each revenue and expenditure mutation has registered so that the balance of the value and quantity of the inventory can determine at any time.

c. Measurement is using the FIFO (First in First Out) or the average method by SAK.

d. At the end of the annual period, the inventory opname will be performed. If there is any difference between the accounting record and physical position of inventory, it will be recognized as a gain or loss to another depending on the difference more or less.

\section{4. $\quad$ Fixed Assets}

a. Estimation of Economic Age and Fixed Assets Depreciation

Fixed assets recorded at cost includes all costs incurred until the assets are ready for use. Self-constructed assets recorded at the entire value of materials/equipment used. Meanwhile, depreciation of fixed assets is calculated using the Straight-line method, based on estimated useful lives, as follows

Table 5. Fixed Assets Depreciation Rate

\begin{tabular}{clcc}
\hline \hline No & Type of Tangible Fixed Assets & Useful Life & Depreciation \\
\hline 1. & Building & 20 years & $5 \%$ \\
2. & Equipment & 4 years & $25 \%$ \\
3. & Vehicle & 8 years & $12,5 \%$ \\
\hline \hline
\end{tabular}

b. Fixed Asset Expenditure

The expenditure on fixed assets for maintenance, addition, renovation, expansion aimed to add 
economic value, increase the capacity and increase the useful life will be capitalized to add the value of the assets.

\section{Debt}

Debt is valued based on purchasing credits, loans from other parties with a certain amount of interest, the expenses have occurred, are presented on the balance sheet following the obligations of the company to the vendor creditors and other parties.

\section{Revenue Recognition}

Revenue recognized at the time of incurred (acceptable) based on valid evidence.

\section{Expenses}

The expenses should be recognized, recorded and reported for the period of the transaction. Payment for periodic transactions such as salaries, electricity, rent, and insurance must attribute to the period in which such expenses occurred, even if payment has not been made or has paid in advance. For the purposes accounting period cutoff, expenses incurred before the date of the balance sheet although not yet known with a certain amount should be recorded and reported with a reasonable estimation.

The following is the example of the procedure or mechanism that can be used to facilitate accounting information system of trading SMEs adopted from Mulyadi [21]

1. Procedures that form credit sales system consists of the procedure of sales orders, credit approval procedures, delivery procedures, billing procedures, procedures for recording accounts receivable, sales distribution procedures, record-keeping procedures of goods sold.

2. Purchasing procedures are comprising a purchase order procedure, procedure requests for quotation and supplier selection, procedures of receiving goods, debt recording procedures, the purchase distribution procedure

3. The procedures that are forming payroll and remuneration system comprise recording of attendance procedures, the procedure of preparing payroll, payroll expense distribution procedure, the procedure of providing cash outflow evidence, and procedure of payment of salaries.

4. Procedures that are forming the system of revenue from cash sales consist of sales order procedures, procedures for cash receipts, goods delivery procedures, procedures for recording cash sales, cash deposits to bank procedures, procedures for recording cash receipts, recording cost of goods sold procedures.

5. Procedures that are forming cash disbursements include the system does not require a cash disbursement check requests and those systems that require a cash disbursement check request

6. Procedures that are forming inventory system consists of inventory recording procedures. Procedures for recording the cost of supplies purchased, procedures for the cost of inventory returned to the supplier, procedure for requests and distribution of inventory from the warehouse, procedure for recording the additional cost of inventories due to the return goods, and procedures for physical inventory opname.

7. The subsystems that are forming the accounting system of fixed asset consist of fixed asset purchasing system, fixed asset acquisition system through its development, capital expenditure systems, discontinuation fixed assets systems, fixed asset transfer system, the system of fixed assets revaluation, and accounting system of fixed asset depreciation.

Meanwhile, the document transactions can be in the shape of a form and recording document 
that routinely used in all organizations. Documents can be in the form of electronic or non-electronic. This document aimed to establish responsibility and as evidence of transactions occurred [14]. Reference [21] highlighted that document or form has the following benefits: assign responsibility for the emergence of the company's business transactions. Data recording of business transactions of the company, reduce the likelihood of error by declaring all the events in writing and delivering basic information from one person to another within the same organization or to other organizations.

Some basic principles need to consider in designing a form for the company's business activities, namely: (1) providing the copy or copies of the form, (2) avoid duplication in data collection, (3) make the form as simple and concise as possible,

The other principles are (4) Integrate the internal check-in designing the form, (5) Include the company name and address on the form to used for communication with external parties

(6) Include the name of the form for easy identification, (7) Give the numbers for a form for easy identification, (8) Include a line number on the left and right side of the form if wide form used, to minimize the possibility of incorrect filling,

The folowing principles are (9) Print out a line on a form, if the form will be filled by hand writing, (10) Include printed serial number, (11) Design a specific form allowed the filler only write sign or $x$, or by answering yes or no, to save time in filling, (12) Prepare a double form with carbon insert disposable or NCR paper, (13) Using the distribution zones allowed the forms divided according to blocks of logical areas containing data related to each other [21].

\subsection{Accounting Information System Implementation}

The process of applying the new or revised accounting information system must have the approval from the management of trading SMEs. The commitment of management is also needed to encourage the implementation of a new information system.

The new system should implement at the beginning of the accounting period. The goal is to reduce the workload arising from the changes that will influence account balances and the use of new procedures in the middle period. If the company uses computerized systems, the application of the new system can perform in conjunction with the old system. Therefore, two systems process the same data. The intended use of the two systems in parallel is to prevent the emergence of new difficulties because the system cannot function properly, thus at the same time can generate two types of information. Both types of information from these two systems can be compared to check the results of the new system processing [14]. If the new system has been tested and settle down, the company can be started not to use the old system.

\subsection{The Supervision of New System}

This phase has an objective to supervise the application of the new system, to verify whether the new system can function properly. If it found an error, then during the period of supervision, it is necessary to make the improvements. The focus of the new system does not repeat existing weaknesses in the old system [14].

\section{Conclusion}

To conclude, trading SMEs as the focus of research has simple accounting information systems implemented in the business activities, but it has not well documented. The results of research on the business process and the analysis of the weaknesses and strengths of the system indicate that the applied accounting information system requires an improvement regarding organizational structure, 
job descriptions, internal control related to inventory and fixed asset management. These results are used as the basis of accounting information to design the new system to repeat the same mistakes in achieving corporate goals.

It requires a pilot model of accounting information system design at trading SMEs that can support the daily operations of the business. Therefore, it is necessary to conduct more accurate mapping of trading SMEs to support the accounting information system. Future research can be developed in the form of the increase in the number of SMEs surveyed, for examples focus on different business activities such as services or manufacturing companies. COSO framework specifically for SMEs can be the alternative for analysis.

\section{Acknowledgment}

We would like to thanks to all of the trading SMEs who participate in this research.

\section{References}

[1] Wijayanti, A. dan Kartika Hendra Ts. (2013). Development of Small and Medium Enterprises (SMEs) Accounting Information System in Cluster of Kampung Laweyan Batik, Surakarta, Indonesia. Chinese Business Review, Vol. 12, No. 10, 698-711.

[2] Amalia, R. (2012). Effect of accounting information systems users against improved managerial performance in banking company in Makasar. Retrieved from http://repository.unhas.ac.id.

[3] Motwani, J., Mirchandani, D., Mandal, M., and Gunasekaran, A. (2002). Successful Implementation of ERP projects: evidence from two case studies. International Journal of Production Economics, Vol. 75, special issue, Information technology/information systems in 21st-century manufacturing, pp. 83-96.

[4] Wang. (2004) Determinants of the adoption of e-business technologies. Telematics and Informatics, 22, 181.

[5] Edison, G., Manuere, M., Joseph, M., and Gutu, K. (2012). Evaluation of Factors Influencing Adoption of Accounting Information System By Small To Medium Enterprises In Chinhoyi. Interdisciplinary Journal of Contemporary Research in Business. Vol. 4, No. 6, pp. 1126-1141.

[6] Mitchell, F. and Reid, G. (2000). Problems, challenges, and opportunities: the small business as a setting for management accounting research. Management Accounting Research, Vol. 11 No. 4, pp. 385-90.

[7] Randall, R. and Horsman, S. (2001). Can failure in SMEs be reduced by better management accounting? Paper presented at 21st ISBA National Small Firms Conference: Celebrating the Small Business.

[8] Kharuddin, S., Ashhari, Z.M., and Nassir, A.M. (2010). Information System and Firms' Performance: The Case of Malaysian Small Medium Enterprises. International Business Research. Vol. 3, No. 4, pp. 28-35. www.ccsenet.org/ibr.

[9] Pollock, N. and Cornford, J. (2004). ERP systems and the university as a unique organization. Information Technology \& People, Vol. 17 No. 1, pp. 31-52.

[10] Ministry of Cooperatives and Micro, Small and Medium Enterprises. (2012). Statistik Usaha Kecil dan Menengah Tahun 2011-2012. Accessed from http://www.depkop.go.id

[11] ACCA. (2015). The Asia Pacific SME Cloud Computing Attractiveness Index 2015. Asia Cloud Computing Association. http://www.asiacloudcomputing.org

[12] Undang-undang Republik Indonesia Nomor 20 Tahun 2008 tentang Usaha Mikro, Kecil dan Menengah. (Constitution of Indonesia no. 20 year of 2008 about Micro Business and Medium 


\section{Enterprises)}

[13] Creswell, J. W. (2014). Research Design: Qualitative, Quantitative, and Mixed Methods Approaches. International Student Edition, Fourth Edition. Sage Publication Asia-Pacific Pte. Ltd. Singapore

[14] Bastian, I. 2006. Sistem Akuntansi Sektor Publik. Penerbit Salemba Empat, Jakarta (Public Sector Accounting System)

[15] Al Hadist -HR Bukhari

[16] QS. Al-Hujurat: 6

[17] QS. Yusuf:55

[18] QS. Al-Baqarah: 245

[19] Warfield, T.D., Weygandt, J. J., Kieso, D. E. (2007). Intermediate Accounting: Principles and Analysis, 2nd Edition. Wiley

[20] IAI. (2009). Standard Akuntansi Keuangan Entitas Tanpa Akuntanbilitas Publik (SAK ETAP). (Financial Accounting Standards Entity Without Public Accountability)

[21] Mulyadi. (2001). Sistem Akuntansi. Penerbit Salemba Empat. Jakarta. (Accounting System. 